Support grows for rival conference on development

Several hundred non-governmental organisations have already expressed interest in participating in an alternative conference which is being planned to take place in parallel with the United Nations Conference on Science and Technology for Development in Vienna at the end of August.

Unlike the official conference, which will concentrate on political mechanisms for stimulating the contributions of science and technology to development, the alternative conference will consider specific topics for action. High on the preliminary agenda are plenary sessions on nuclear energy in Third World countries, environmental aspects of development, the role of multinational corporations, and the implications of the arms race. These sessions will take place in Vienna's Kongresshaus.

A number of working groups are also planned, to run for the full ten days of the conference (August 19 to 29) with the aim of producing specific proposals for action. In particular, there will be discussions about information and financial mechanisms that might be established to support the work of non-governmental organisations after the conference. "This is one of the most important things that we can do at Vienna", says Dr Karim Ahamed of the Natural Resources Defense Council in New York, chairman of the conference organising committee.

"We want to see the extent to which non-governmental organisations can, for example, stimulate technology assessment activities in Third World countries which could be brought to bear on government efforts. And we also want to find out what private and public sources of funding are available to support these efforts."

The organising committee, which has a planning board made up of 14 international organisations, is already preparing an extensive document commenting on the proposals for action that will be discussed at the official conference, and pointing out areassuch as the need for appropriate technologies, or the role of women in development-which it feels have been neglected in official discussions.

"One particular goal will be to see if we can create mechanisms for monitoring what happens after UNCSTD, and exposing it to public view in an effort to make governments keep up to their promises," Mr Ward Morehouse, another member of the committee, said.

\title{
Max Planck Society sets up three new research institutes-and cuts off support for others
}

THE Max Planck Gesellschaft (MPG), which spends DM750 million a year on research in West Germany, has started to renew and restructure several of its 50 institutes. It is following a tradition of, from time to time, taking up new fields in exchange for others that have matured or have not developed according to the MPG's expectations.

Last March, the MPG Senate, for the first time in five years, approved the setting up of new institutes (MPI) and gave the green light for three of them straightaway: an MPI of Quantum Optics (Directors: Professors KarlLudwig Kompa, Herbert Walter and Siegbert Witkowski); an MPI of Psycholinguistics (Director: Professor Dr Willem J. M. Levelt); and an MPI of International and Foreign Social Legislation (Director: Professor Dr Hans F. Zacher).

In addition, one or two project groups working closely with clinical establishments (eg in universities) are to be set up to augment medical research within MPG. The content and orientation of their research is not yet decided, but it is likely that cancer research will be among the new fields.

The decisions to set up the three new institutes have been taken after several years of successful work by project groups. (This is an important condition within the MPG for the establishment of a new institute.) The new MPI of Quantum Optics is building on the work of the project group for laser research, which itself was hived off four years ago from the MPI of Plasma Physics (IPP). And the future Institute of Psycholinguistics, which will research the structure and use of natural language is building on work already done at the Netherlands University of Nijmegen. The decision to site the latter at Nijmegen is seen as an example of MPG's emphasis on European cooperation. The MPG, which is financed jointly by the federal research ministry and the Länder, hopes to fund its new activities from higher growth rates in the budget (6-8\% per annum instead of an average of about $3 \%$ during recent years of stagnation).

The MPG has also decided to close down work at two of its institutes. Terminating work in a particular field or closing an entire institute is usually done when similar research is being carried out in universities and other research establishments (and mostly when the head of the institute retires).
Thus Professor Jürgen Aschoff's research at the MPI of Behavioural Physiology runs out with his retirement because biorhythms are being researched simultaneously at other places. (His famous 'bunker' will continue to be available to researchers!) For similar reasons the work on nuclear physics at the MPI of Chemistry in Mainz is to run out and be replaced by the new main field of geochemistry.

On average, over the past 10 years, one institute or department within the MPG has been closed or transferred to another agency each year. In the majority of cases the public has been aware of little of the concomitant tensions or problems. Not so, however, in the case of the institute founded in 1970 by Carl Friedrich von Weizsäcker in Starnberg with the ambitious title of Max Planck Institute of Research into the Living Conditions of the ScientificTechnological World. The founding of the institute created a stir in particular because of the all-embracing formulation of its brief (which prompted Der Spiegel on one occasion to talk of a 'Faustian' project); the overt attempt by industrialists to influence its policy; and the appointment of the neoMarxist Jürgen Habermas as codirector.

Doubts later grew about the efficiency of the institute, which seemed to be concentrating on isolated projects. Even though one or two noteworthy pieces of work were done, the commissions, set up as a rule four years before the retirement of an institute head, started to discuss the end of the institute in its existing form. After intensive discussions the MPG Senate decided not to continue the work of Herr von Weizsäcker after his retirement "since there is no one to replace him".

Instead, a new MPI of Social Sciences is being set up, which will have four departments and according to Professor Reimar Lüst, President of the MPG, who was talking during the MPG's general meeting in Mainz last month, "is advancing no sweeping claim for the social sciences, any more than would an Institute of Physics or Biology in our society". Ralf Dahrendorf, at present Director of the London Schol of Economics and Political Science, was appointed as an additional director with Jürgen Habermas. Two more departments are envisaged for a political scientist and a psychologist.

Klaus Höpf ner 